\title{
PEMBERDAYAAN MASYARAKAT BERBASIS PENYUSUNAN LAPORAN KEUANGAN SEDERHANA PADA KELOMPOK USAHA TANI PEMBIBITAN TANAMAN BUAH
}

\section{EMPOWERMENT OF COMMUNITY BASED ON DEVELOPMENT OF SIMPLE FINANCIAL STATEMENTS IN FRUIT SEEDING PLANTS}

\author{
I C Kusuma1a, L Wuryanto' ${ }^{1}$ \\ ${ }^{1}$ Program Studi Akutansi , Fakultas Ekonomi, Universitas Djuanda Bogor \\ Jl. Tol Ciawi No. 1, Kotak Pos 35 Ciawi, Bogor 16720. \\ a Korespondensi: Indra Cahya Kusuma, Email: indracahya.k@unida.ac.id \\ (Diterima: 18-12-2018; Ditelaah: 20-12-2018; Disetujui: 08-01-2019)
}

\begin{abstract}
Micro and Small Enterprises (MSE) engaged in agriculture, especially breeding / breeding of fruit trees in the City and District of Bogor, especially in the Nagrog Village, South Bogor District and Karacak Village, Leuwiliang District, are still relatively small. Breeding / nursery activities are generally carried out in groups and from generation to generation, with traditional management and simple seed breeding techniques. There are several obstacles faced by farmers, including; limited capital, lack of production facilities and infrastructure and not understanding Accounting, especially never registering and not knowing how to prepare financial statements. This activity aims to increase economic capacity through the preparation of simple financial reports for fruit nursery farmer groups. The method used is in the form of counseling, training, mentoring and strengthening with techniques for recording transactions into journals, calculating the cost of goods, income statement and statement of financial position / balance sheet. The results of the activity indicate a change in mindset and knowledge in accounting. The farmer group has been orderly recording and can calculate the profit or loss of fruit plant nursery business.
\end{abstract}

Keywords: Empowerment, farmer groups, simple financial statements

\begin{abstract}
ABSTRAK
Usaha Mikro dan Kecil (UMK) yang bergerak dibidang pertanian, terutama penangkaran/pembibitan tanaman buah di Kota dan Kabupaten Bogor, khususnya di Kampung Nagrog Kecamatan Bogor Selatan dan Desa Karacak Kecamatan Leuwiliang masih relatif sedikit. Kegiatan penangkaran/pembibitan tanaman buah pada umumnya dilakukan secara berkelompok dan turun temurun, dengan manajemen tradisional dan teknik penangkaran bibit yang sederhana. Ada beberapa kendala yang dihadapi petani, antara lain; keterbatasan modal, kurangnya sarana dan prasarana produksi serta tidak mengerti Akuntansi, terutama tidak pernah melakukan pencatatan dan tidak tahu menyusun laporan keuangan. Kegiatan ini bertujuan untuk meningkatkan kapasitas ekonomi melalui penyusunan laporan keuangan sederhana bagi kelompok tani pembibitan buah. Metode yang dilakukan berupa penyuluhan, pelatihan, pendampingan dan penguatan dengan tehnik pencatatan transaksi kedalam jurnal, perhitungan harga pokok, laporan laba rugi dan laporan posisi keuangan/neraca. Hasil kegiatan menunjukan adanya perubahan pola pikir dan pengetahuan dalam akuntansi. Kelompok tani sudah tertib melakukan pencatatan dan dapat menghitung laba atau kerugian usaha pembibitan tanaman buah.
\end{abstract}


Kata Kunci : Laporan keuangan sederhana, kelompok tani, pemberdayaan.

\author{
Kusuma, I, C., \& Wuryanto, M. (2019). Pemberdayan Masyarakat Berbasis Penyusuanan Laporan \\ Keuangan Sederhana Pada Kelompok Usaha Tani Pembibitan Tanaman Buah . Jurnal Qardhul \\ Hasan: Media Pengabdian kepada Masyarakat, 5(1), 23-27.
}

\section{PENDAHULUAN}

Usaha Mikro dan Kecil (UMK) yang bergerak dibidang pertanian, terutama penangkaran/pembibitan tanaman buah di Indonesia khususnya di Kota dan Kabupaten Bogor masih relatif sedikit. Untuk itu lah berdasarkan renstra Kementrian Pertanian arah kebijakan 2015 - 2019, dimana dalam pengembangan sistem pembenihan produk hortikultura akan dilakukan penguatan terhadap 158 kelembagaan penangkar pembenihan (Biro Perencanaan, 2015). Kegiatan penangkaran/pembibitan tanaman buah pada umumnya dilakukan secara berkelompok dan turun temurun, dengan manajemen tradisional dan teknik penangkaran bibit yang sederhana. Keberadaan petani penangkar bibit tersebut sangat vital dalam rangka memenuhi permintaan bibit di pasaran. Namun di sisi lain mereka sering tidak berdaya menghadapi pedagang atau tengkulak bibit yang menguasai akses permodalan dan jaringan pemasaran. Ini dikarenakan keterbatasan modal, kurangnya sarana dan prasarana produksi serta pengetahuan tentang pertanian dan Akuntansi dalam pencatatan dan pengelolaan keuangan. Salmiah, (Indarti dan Siregar, 2015).

Kelompok Tani Unggul Raya merupakan usaha mikro dan kecil (UMK) yang bergerak dibidang pembibitan tanaman manggis, pala dan cengkeh di Kampung Cengal RW 05 Desa Karacak Kecamatan Leuwiliang Kabupaten Bogor. Lokasi tersebut dipilih antara lain dengan pertimbangan : Merupakan daerah sentra perkebunan tanaman manggis varietas Raya di Kabupaten Bogor; secara turun temurun terdapat petani penangkar bibit tanaman manggis dan pala, serta; secara secara akroklimat cocok untuk pembibitan tanaman manggis, pala dan cengkeh. Berbagai aktivitas di Pusat Pembibitan Manggis, Pala dan cengkeh di Kampung Cengal RW 05 Desa Karacak antara lain adalah: Sebagai tempat agribisnis pembibitan tanaman manggis, pala dan cengkeh secara profesional, sebagai tempat edukasi dan konsultasi agribisnis khususnya pengembangan bibit dan agribisnis tanaman manggis, pala dan cengkeh, serta sebagai tempat pelatihan teknik perbanyakan bibit tanaman manggis, pala dan cengkeh.

Kelompok Usaha Tani (KUT) Amiri Tani Mandiri merupakan wadah berkumpulnya para petani produsen bibit tanaman buah-buahan tropis khususnya bibit tanaman durian. KUT Amiri Tani Mandiri berdiri pada tahun 2012 yang dipelopori oleh Riyo Sudarpo. Jumlah anggota pada saat sekarang 17 orang. Lokasi lahan usaha produksi bibit tanaman buah-buahan tersebut terletak di Kampung Nagrog RW 12 Kelurahan Pamoyanan, Kecamatan Bogor Selatan, Kota Bogor.

Bibit tanaman buah yang diproduksi oleh KUT Amiri Tani Mandiri meliputi tanaman; nangka mini, durian dan pala. Penangkaran tanaman buah diperoleh dari hasil teknis okulasi dengan mata tunas dari pohon induk yang tersertifikasi oleh instansi terkait, sehingga terjaga kualitas bibit yang dihasilkan.

Gambar 1. Pembibitan tanaman buah.

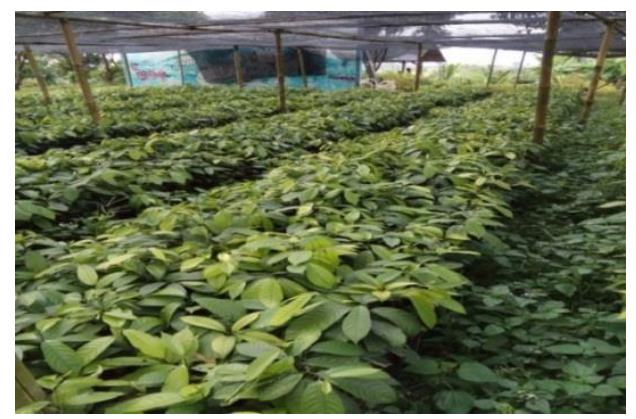

Bibit yang dihasilkan oleh KUT Amiri Tani Mandiri diminati berbagai kalangan konsumen, di ataranya: Pengusaha swasta di bidang perkebunan; perusahaan perkebunan milik pemerintah; proyek dan program pemerintah dan swasta; para pedagang bibit (retailer); Jangkauan pemasaran bibit produksi KUT Amiri Tani Mandiri sangat luas, meliputi : Jawa, Bali, Lombok, Sumatera, dan beberapa wilayah lain di Indonesia.

Kendala yang dihadapi oleh KUT Amiri Tani Mandiri adalah keterbatasan permodalan untuk meningkatkan jumlah produksi bibit serta keterbatasan sarana dan prasarana, pendidikan dan pelatihan untuk meningkatkan produk sehingga lebih berkualitas. Senada dengan penelitian Akhmadi, (Siregar dan Hutagaol, 2016) kendala yang dihadapi Gabungan Kelompok Tani adalah kurangnya pelatihan, keterbatasan dana, dan rumitnya penyaluran kredit. (Bairwa et al, 
2014), bahwa pentingnya manajemen pendidikan agrobisnis dapat menciptakan tenaga terdidik dan peluang usaha dan bisnis. Kurangnya pengetahuan akan Akuntansi dan keuangan menjadi penghambat untuk mendapatkan akses permodalan dari perbankan. Berikut gambaran produksi pembibitan tanaman buah KUT Amiri Tani Mandiri.

\section{Rumusan Masalah}

Berdasarkan hasil observasi pada Kelompok Tani "Unggul Raya" yang berada di Kampung Cengal Desa Karacak Kecamatan Leuwiliang Kabupaten Bogor dan Kelompok Tani "Amiri Tani Mandiri" di Kampung Nagrog Kelurahan Pamoyanan Kecamatan Bogor Selatan Kota Bogor berkaitan dengan biaya-biaya yang dikeluarkan dalam usaha pembibitan tanaman buah dari mulaia pra penanaman, penanaman, pemeliharaan, panen dan pasca panen. Permasalahan yang dihadapi para petani pembibit adalah : Tidak memiliki pengetahuan Akuntansi; tidak memahami perhitungan harga pokok produksi; dan tidak memahami pencatatan laporan keuangan.

\section{MATERI DAN METODE}

\section{Tahapan}

Dalam memecahkan masalah pada Kelompok Usaha Tani "Unggul Raya" dan "Amiri Tani Mandiri" dalam akuntansi, perhitungan harga pokok produksi dan pengelolaan keuangan, langkah-langkahnya adalah: Mengadakan survey dan observasi terhadap mitra Kelompok Usaha Tani "Unggul Raya" dan "Amiri Tani Mandiri"; mempersiapkan bahan/materi pelatihan akuntansi keuangan sederhana; persiapan tim tutorial pelatihan; melaksanakan pelatihan berupa konsep dan praktik akuntansi keuangan; Monitoring dan Evaluasi hasil pelatihan; Publikasi ilmiah di jurnal/prosiding; laporan pelaksanaan Program Kemitraan Masyarakat.

\section{Metode Pendekatan}

Dalam pelaksanaan Program Kemitraan Kegiatan Masyarakat, metode pendekatan yang digunakan dengan melakuakan pelatihan berupa konsep dan pratik dalam mengatasi permasalahan mitra berupa lemahnya dalam akuntansi, perhitungan harga pokok dan pengelolan keuangan, untuk memahami Akutansi, maka pendekatan melalui ceramah, diskusi, pratik bagaimana; mencatat, menghitung harga pokok produksi dan membuat laporan keuangan sederhana.

\section{Tempat dan Waktu Pelaksanaan}

Tempat pelatihan akan dilaksanakan di dua lokasi yang berbeda. Pertama dilaksanakan di Kampung Cengal Rt. 02/05 Desa Karacak Kecamatan Leuwiliang Kabupaten Bogor.

Gambar 2. Bersama warga Desa Karacak

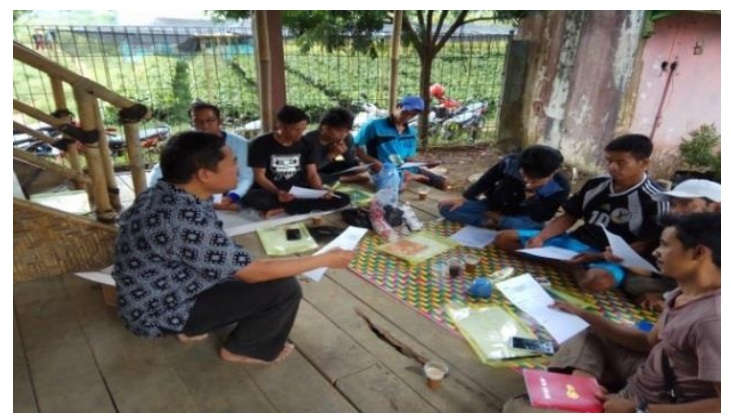

Kedua dilaksanakan di Kampung Nagrog Rt. 05/12 Kelurahan Pamoyanan Kecamatan Bogor Selatan Kota Bogor. Target sasaran adalah anggota masing-masing kelompok usaha tani. Sebanyak 10 orang/kelompok tani. Secara keseluruhan ada 20 orang.

Gambar 3. Kelompok Usaha tani.

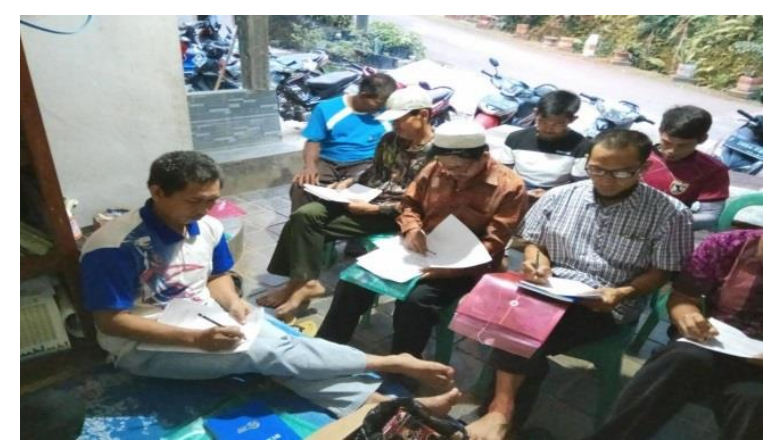

Waktu pelaksanaan dimulai pukul 15:00 - 16:00 dengan system pembelajaran pengenalan konsep akutansi selama 60 menit dan 120 menit pratik akutansi sehingga waktu yang dibutuhkan selama 2 hari.

\section{HASIL KEGIATAN}

Sebelum dilaksanakannya kegiatan pengabdian kepada masyarakat, dilakukan survey dan pemetaan tempat dan lokasi pelaksanaan kegiatan. Sebelum dilaksanakan kegiatan, tim pengabdian melakukan koordinasi dengan Yayasan Amiri Bogor selaku Pembina dari Kelompok Tani “Amiri Tani Mandiri” yang berada di Kampung Nagrog Kelurahan Pamoyanan 
Kecamatan Bogor Selatan Kota Bogor dan Kelompok Tani "Unggul Raya" yang berada di Kampung Cengal Desa Karacak Kecamatan Leuwiliang Kabupaten Bogor.

Untuk memudahkan jalannya penyuluhan dan pelatihan kepada 2 kelompok tani, dilakukan sosialisasi materi pelatihan akuntansi keuangan sederhana yang akan diberikan kepada calon peserta di dua kelompok tani. Hasil observasi dan analisis awal menunjukan, calon peserta: Tidak memiliki pengetahuan akuntansi; Setiap kegiatan yang berhubungan dengan pembelian benih, penanaman, pemeliharan sampai dengan bibit siap dijual, tidak pernah dilakukan pencatatan; Tidak tahu apa itu laporan keuangan dan bagaimana cara membuatnya.

Berdasarkan hasil observasi dan analisis tersebut perlunya dilaksanakan kegiatan pengabdian kepada masyarakat yang dilakukan secara berkesinambunagan oleh Tim Prodi Akuntansi Fakultas Ekonomi Universitas Djuanda dengan melibatkan unsur-unsur dari LPPM Universitas Djuanda dan Yayasan Amiri Bogor sebagai Mitra binaan dari 2 kelompok tani. Ini dikarenakan rencana kegiatan pelatihan penyusunan laporan keuangan sederhana belum pernah dilakukan pada kelompok tani ini. Kegiatan ini melibatkan 12 peserta dimasingmasing kelompok usaha tani pembibitan atau penangkaran tanaman buah. Keseluruhan peserta berjumlah 24 orang.

Adapun kegiatan pelatihan dibagi menjadi 6 kali pertemuan. Dengan kegiatan sebagai berikut; Pada pertemuan pertama pelatihan, masingmasing kelompok dibekali tehnik kewirausahaan yang dipandu oleh nara sumber yang ahli dibidangnya berupa tehnik pembibitan, pemeliharaan dan tehnik memasarkan tanaman.

Gambar 4. Bekali tehnik kewirausahaan.

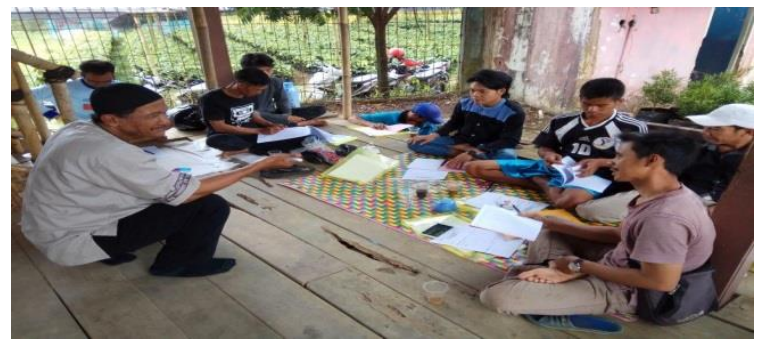

kedalam buku kas. Pada pertemuan ke-3 kelompok tani diajarkan bagaimana menghitung harga pokok produksi dan harga pokok penjualan. Dipertemuan ke-4 para peserta diajarkan bagaimana membuat laporan keuangan, berupa laporan laba rugi. Pada pertemuan ke-5 para peserta pelatihan diajarkan bagaimana membuat laporan perubahan ekuitas dan dipertemuan terakhir atau ke-6 diajarkan membuat laporan posisi keuangan atau neraca.

Setelah dilaksanakannya pelatihan selama $6 \mathrm{kali}$ pertemuan dimasing-masing kelompok tani yang berada di Kampung Cengal Desa Karacak Kecamatan Leuwiliang Kabupaten Bogor dan di Kampung Nagrog Kelurahan Pamoyanan Kecamatan Bogor Selatan Kota Bogor.

Gambar 5. Pertemuan ke 6 kelompok tani.

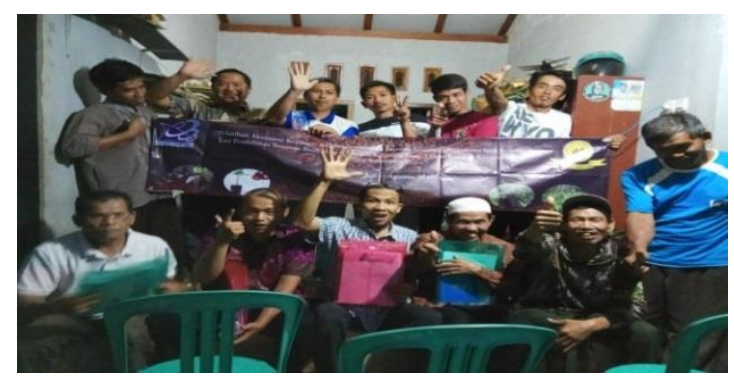

Terlihat adanya perubahan pola pikir dan pengembangan wawasan dari masing-masing kelompok tani. Ini dapat dilihat dari mulai tertariknya para kelompok tani untuk memulai melakukan pencatatan/pembukuan setiap terjadinya transaksi usaha. Mulai mengerti melakukan perhitungan harga pokok produksi dan harga pokok penjualan. Mulai memahami bagaimana membuat laporan keuangan berupa laba rugi.

\section{KESIMPULAN DAN SARAN}

\section{Kesimpulan}

Berdasarkan hasil pretest sebelum kegiatan dilaksanakan dan kuisioner disebarkan ke 12 peserta pelatihan dimasing-masing kelompok usaha tani, para peserta pelatihan; tidak pernah melakukan pencatatan setiap terjadinya transaksi yang bersifat keuangan; peserta tidak tahu dan tidak mengerti cara perhitungan dan penyusunan laporan harga pokok produksi dan harga pokok penjualan; peserta tidak mengerti dan tidak tahu menyusun laporan keuangan sederhana berupa laporan Laba Rugi, Laporan Perubahan Modal dan Laporan Posisi Keuangan/Neraca.

Setelah dilaksanakan kegiatan berupa penyuluhan, pelatihan dan pendampingan selama 6 kali pertemuan dimasing-masing kelompok usaha tani, sebagian besar para peserta pelatihan; memulai melakukan pencatatan setiap terjadinya transaksi; mulai memahami cara perhitungan dan penyusunan harga pokok produksi dan harga pokok penjualan; mulai memahami cara menyusun laporan keuangan sederhana. 


\section{Saran}

Sebaiknya adanya proses pembelajaran yang berkelanjutan dan berkesinambungan bagi Usaha Mikro dan Kecil (UMK) di sektor pertanian, terutama para kelompok usaha pembibitan tanaman buah yang tersebar di Kota dan Kabupaten Bogor. Diharapkan para petani dapat membuka wawasan tidak hanya memproduksi dan memasarkan hasil usaha, akan tetapi mereka dapat menghitung skala produksi dan membukukannya dalam bentuk laporan keuangan sederhana.

Perlu peran serta aktif pemerintah, terutama pemerintahan daerah dan desa dengan melakukan pendataan keragaan para petani pembibit tanaman buah. Disamping itu mengalokasikan sebagian anggaran untu kegiatan pelatihan, pendampingan dan penguatan dalam akuntansi dan pengelolaan keuangan bagi UMK yang bergerak dibidang usaha pembibitan/ penangkaran tanaman buah.

\section{DAFTAR PUSTAKA}

Adiyoga W. 2010. PerkembanganRantai Pasok Akhmadi, Siregar, Hermanto dan Hutagaol, Parulian. M, 2016, Pengembangan Agrobisnis Sebagai Strategi Penanggulangan Kemiskinan di Pedesaan, Jurnal Manajemen dan Agrobisnis, Vol. 13, No.3, Hal. 240-253.

Bairwa SL et al., 2014. Agribusiness Management Education: A Review on Employment Opportunities, International Journal Scientific and Publication 4(2): 1-4.

Bank Indonesia. 2015. Pedoman Umum Pencatatan Transaksi Keuangan Usaha Kecil Badan Usaha Bukan Badan Hukum, Jakarta.

Biro Perencanaan, Sekretariat Jenderal, 2015. Rencana Strategis Kementerian Pertanian Tahun 2015 - 2019, Kementerian Pertanian, Jakarta.

Direktorat Riset dan Pengabdian Kepada Masyarakat, 2017. Panduan Pelaksanaan Penelitian dan pengabdian Kepada Masyarakat Edisi XI, Kementerian Riset Teknologi dan Pendidikan Tinggi, Jakarta.

Ikatan Akuntan Indonesia (IAI). 2016. Standar Akuntansi Keuangan Entitas Tanpa Akuntabilitas Publik (SAK-ETAP), Jakarta.

Kieso, E.Donald, Weygandt J.Jerry and Warfield D.Terry, 2007. Akuntansi Intermediate, Edisi Keduabelas, Penerbit Erlangga, Jakarta.

Salmiah, Neneng, Indarti dan Siregar, Fitri Inova. 2015. Analisis Penerapan Akuntansi dan Kesesuaiannya dengan SAK ETAP, Jurnal Akuntansi, Vol. 3, No. 2, Hal. 212-226. 